\title{
Methoxylaricinolic Acid, a New Sesquiterpene from the Fruiting Bodies of Stereum ostrea
}

\author{
Young-Hee Kim, Bong-Sik Yun, In-Ja Ryoo, Jong-Pyung Kim, Hiroyuki Koshino, \\ Ick-Dong Yoo
}

Received: May 18, 2006 / Accepted: July 19, 2006

(C) Japan Antibiotics Research Association

\begin{abstract}
Methoxylaricinolic acid (1), a new sesquiterpene with drimane skeleton was isolated from the fruiting bodies of Stereum ostrea, together with the known compound laricinolic acid (2). The structure of 1 was determined as 12-methoxy-7-oxo-11-drimanoic acid on the basis of spectroscopic analysis.
\end{abstract}

Keywords methoxylaricinolic acid, Stereum ostrea, chemical structure

Stereum species produce many unique secondary metabolites including sesquiterpenes such as hirsutane [1], sterepolide [2] and sterpurene [3], benzaldehydes [4] and benzofurans [5]. In our previous studies on Stereum spp., several antioxidants, hirsutenols $\mathrm{A} \sim \mathrm{C}[6]$ and sterins $\mathrm{A}$, $B$ [7] and C [8] were isolated from the culture broth of Stereum hirsutum (Willd.: Fr) S. F. Gray (stereaceae). As part of our continuing search for naturally occurring bioactive substances from Stereum spp., a new sesquiterpene, methoxylaricinolic acid (1), along with the known compound, laricinolic acid (2), has been isolated from the methanolic extract of the fruiting bodies of Stereum ostrea. In this paper, we describe the isolation, physico-chemical properties, structure determination and antioxidant activity of these compounds.

The air-dried fruiting bodies of Stereum ostrea ( $450 \mathrm{~g}$ ) were crushed and extracted three times with methanol at

I.-D. Yoo (Corresponding author), Y.-H. Kim, B.-S. Yun, I.-J. Ryoo, J.-P. Kim: Laboratory of Antioxidants, Korea Research Institute of Bioscience and Biotechnology, Daejeon 305-333, Korea, E-mail: idyoo@kribb.re.kr room temperature. The combined extract was concentrated in vacuo to give a syrup, which was partitioned between chloroform and water. The chloroform-soluble part $(7.7 \mathrm{~g})$ was subjected to silica gel column chromatography and eluted by a gradient with increasing amount of methanol in chloroform (from 100:1 to $1: 1, \mathrm{v} / \mathrm{v}$ ) to give an active fraction. The active fraction was chromatographed on a column of Sephadex LH-20 eluting with chloroform/ methanol $(1: 1, \mathrm{v} / \mathrm{v})$, followed by HPLC using a YMC pack ODS-A column $(4.6 \mathrm{~mm}$ i.d. $\times 150 \mathrm{~mm})$ eluting with acetonitrile/water $(70: 30, \mathrm{v} / \mathrm{v})$ to afford compounds 1 and 2 having retention times of 10.4 and 13.5 minutes, respectively.

The physico-chemical properties of methoxylaricinolic acid (1) are as follows; yellow oil, $[\alpha]_{\mathrm{D}}-80.0^{\circ}(c 0.01$, $\mathrm{MeOH})$, high resolution EI-mass $m / z 282.1542 \mathrm{M}^{+}$ $\left(\mathrm{C}_{16} \mathrm{H}_{26} \mathrm{O}_{4}\right.$ requires 282.1533), UV $\lambda_{\max } \mathrm{nm}(\mathrm{MeOH}) 208$

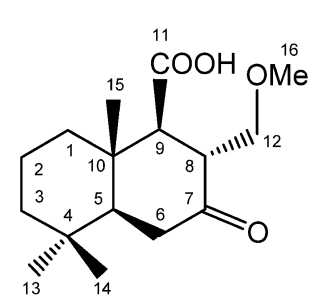

Methoxylaricinolic acid (1)

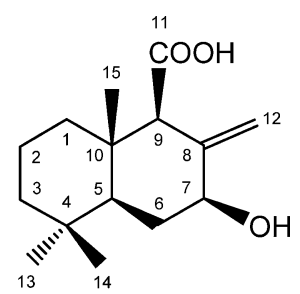

Laricinolic acid (2)
Fig. 1 Structures of methoxylaricinolic acid (1) and laricinolic acid (2).

H. Koshino: RIKEN, 2-1 Hirosawa, Wako, Saitama 351-0198, Japan 
(3.70), 281 (2.90), 314 (2.61) nm, IR (KBr) 3366, 1717, $1606,1512,1272,1058 \mathrm{~cm}^{-1}$. Its molecular formula was determined as $\mathrm{C}_{16} \mathrm{H}_{26} \mathrm{O}_{4}$ by the high-resolution EI-mass measurement. A close inspection of the ${ }^{1} \mathrm{H}$ and ${ }^{13} \mathrm{C}$ NMR spectra (Table 1) of $\mathbf{1}$ by DEPT and HMQC experiments revealed the presence of three tertiary methyl (C-13, C-14 and C-15), five methylenes (C-1, C-2, C-3, C-6 and $\mathrm{C}-12)$ including one oxygen-bearing carbon $(\mathrm{C}-12)$, three methines (C-5, C-8 and C-9), one methoxyl methyl carbon (C-16) and four quaternary carbons (C-4, C-7, C-10 and $\mathrm{C}-11)$. The ${ }^{13} \mathrm{C}$ chemical shifts of two downfield signals corresponding to $\mathrm{C}-7 \quad\left(\delta_{\mathrm{C}} 213.8\right)$ and $\mathrm{C}-11$ $\left(\delta_{\mathrm{C}}\right.$ 178.4) suggested the presence of a ketone and a carboxyl group, respectively. The ${ }^{1} \mathrm{H}-{ }^{1} \mathrm{H}$ COSY data revealed three partial structures; $-\mathrm{CH}_{2}-\mathrm{CH}_{2}-\mathrm{CH}_{2}-$, $-\mathrm{CH}-\mathrm{CH}_{2}-$ and $-\mathrm{CH}-\mathrm{CH}-\mathrm{CH}_{2}-$. The partial structures were connected by the aid of HMBC spectrum, which displayed ${ }^{1} \mathrm{H}-{ }^{13} \mathrm{C}$ long-range couplings from two singlet methyl protons at $\delta 0.85$ and 0.90 to C-3 $\left(\delta_{\mathrm{C}} 42.7\right)$, C-4 $\left(\delta_{\mathrm{C}} 34.4\right)$ and $\mathrm{C}-5\left(\delta_{\mathrm{C}} 54.6\right)$, from a methine proton at $\delta$ 1.36 to $\mathrm{C}-4\left(\delta_{\mathrm{C}} 34.4\right), \mathrm{C}-9\left(\delta_{\mathrm{C}} 62.4\right), \mathrm{C}-10\left(\delta_{\mathrm{C}} 37.7\right)$ and $\mathrm{C}-13\left(\delta_{\mathrm{C}} 33.4\right)$, from a methylene protons at $\delta 2.33$ and
2.40 to $\mathrm{C}-7\left(\delta_{\mathrm{C}} 213.8\right)$ and $\mathrm{C}-10\left(\delta_{\mathrm{C}} 37.7\right)$, from a methine proton at $\delta 2.83$ to $\mathrm{C}-7\left(\delta_{\mathrm{C}} 213.8\right)$ and C-9 $\left(\delta_{\mathrm{C}} 62.4\right)$, from a methine proton at $\delta 2.36$ to $\mathrm{C}-1\left(\delta_{\mathrm{C}} 40.7\right), \mathrm{C}-10$ $\left(\delta_{\mathrm{C}} 37.7\right), \mathrm{C}-11\left(\delta_{\mathrm{C}} 178.4\right)$ and $\mathrm{C}-15\left(\delta_{\mathrm{C}} 14.7\right)$, from a methyl protons at $\delta 1.23$ to $\mathrm{C}-1\left(\delta_{\mathrm{C}} 40.7\right), \mathrm{C}-5\left(\delta_{\mathrm{C}} 54.6\right)$, $\mathrm{C}-9\left(\delta_{\mathrm{C}} 62.4\right)$ and $\mathrm{C}-10\left(\delta_{\mathrm{C}} 37.7\right)$ and from a methoxyl methyl protons at $\delta 3.25$ to $\mathrm{C}-12\left(\delta_{\mathrm{C}} 70.9\right)$. These correlations unambiguously led the structure of $\mathbf{1}$ as 12-methoxy-7-oxo-11-drimanoic acid (Fig. 2). The relative stereochemistry of $\mathbf{1}$ was established by the NOE correlations from $13-\mathrm{CH}_{3}$ to $5-\mathrm{H}(\delta 1.36)$ and $6-\mathrm{H}(\delta 2.33)$, from $14-\mathrm{CH}_{3}$ to $2-\mathrm{H}(\delta 1.65), 6-\mathrm{H}(\delta 2.40)$ and from

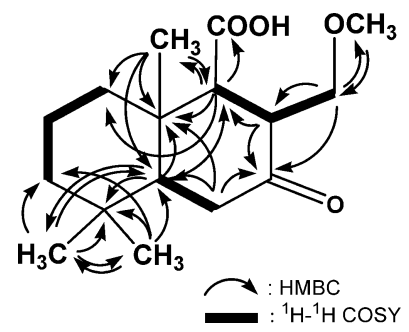

Fig. $2 \mathrm{HMBC}$ correlations of methoxylaricinolic acid (1).

Table $1{ }^{1} \mathrm{H}$ and ${ }^{13} \mathrm{C}$ NMR data of methoxylaricinolic acid and laricinolic acid in $\mathrm{CD}_{3} \mathrm{OD}$

\begin{tabular}{|c|c|c|c|c|}
\hline \multirow{2}{*}{ Position } & \multicolumn{2}{|c|}{ Methoxylaricinolic acid } & \multicolumn{2}{|r|}{ Laricinolic acid } \\
\hline & $\delta_{\mathrm{C}}$ & $\delta_{\mathrm{H}}$ & $\delta_{\mathrm{C}}$ & $\delta_{\mathrm{H}}$ \\
\hline \multirow[t]{2}{*}{1} & 40.7 & $1.37(\mathrm{~m})$ & 39.8 & $1.19(\mathrm{~m})$ \\
\hline & & $1.76(\mathrm{~m})$ & & $1.65(\mathrm{~m})$ \\
\hline \multirow[t]{2}{*}{2} & 19.7 & $1.48(\mathrm{~m})$ & 19.9 & $1.17(\mathrm{~m})$ \\
\hline & & $1.65(\mathrm{~m})$ & & $1.65(\mathrm{~m})$ \\
\hline \multirow[t]{2}{*}{3} & 42.7 & $1.22(\mathrm{~m})$ & 42.9 & $1.23(\mathrm{~m})$ \\
\hline & & $1.46(\mathrm{~m})$ & & $1.46(\mathrm{~m})$ \\
\hline 4 & 34.4 & & 34.2 & \\
\hline 5 & 54.6 & $1.36(d d, 13.7,3.9)$ & 53.7 & $1.18(\mathrm{dd}, 12.9,2.2)$ \\
\hline \multirow[t]{2}{*}{6} & 39.9 & $2.33(\mathrm{dd}, 15.6,3.9)$ & 34.2 & 1.35 (ddd, $12.9,12.0,10.8)$ \\
\hline & & $2.40(\mathrm{dd}, 15.6,13.7)$ & & $2.03(\mathrm{ddd}, 12.0,5.6,2.2)$ \\
\hline 7 & 213.8 & & 73.3 & 3.99 (br dd, 10.8, 5.6) \\
\hline 8 & 51.3 & $2.83(\mathrm{ddd}, 12.7,4.4,2.0)$ & 147.6 & \\
\hline 9 & 62.4 & $2.36(d, 12.7)$ & 62.6 & 2.70 (br s) \\
\hline 10 & 37.7 & & 39.9 & \\
\hline 11 & 178.4 & & 174.7 & \\
\hline \multirow[t]{2}{*}{12} & 70.9 & $3.36(\mathrm{dd}, 9.3,4.4)$ & 105.8 & 4.80 (s) \\
\hline & & $3.73(\mathrm{dd}, 9.3,2.0)$ & & 5.20 (s) \\
\hline 13 & 33.4 & $0.85(s)$ & 33.9 & 0.92 (s) \\
\hline 14 & 21.5 & 0.90 (s) & 22.2 & 0.87 (s) \\
\hline 15 & 14.7 & 1.23 (s) & 14.7 & 1.05 (s) \\
\hline 16 & 59.3 & 3.25 (s) & & \\
\hline
\end{tabular}

Chemical shifts in ppm from TMS as internal standard.

${ }^{1} \mathrm{H}$ and ${ }^{13} \mathrm{C}$ NMR were measured at $600 \mathrm{MHz}$ and $150 \mathrm{MHz}$, respectively. 
$15-\mathrm{CH}_{3}$ to $2-\mathrm{H}(\delta 1.65), 6-\mathrm{H}(\delta 2.40)$ and $8-\mathrm{H}(\delta 2.83)$ and $15-\mathrm{H}(\delta 1.23)$ and from $9-\mathrm{H}$ to $1-\mathrm{H}(\delta 1.37)$ and $5-\mathrm{H}(\delta$ 1.36), and was identical to that of laricinolic acid (2) described below. The co-occurrence in the fruiting bodies of Stereum ostrea and the same relative stereochemistry of $\mathbf{1}$ and $\mathbf{2}$ suggested that the absolute stereochemistry of $\mathbf{1}$ might be identical to that of $\mathbf{2}$. Based on the evidence described above, methoxylaricinolic acid was assigned as a new sesquiterpene of drimane skeleton.

The molecular formula of laricinolic acid (2) was established as $\mathrm{C}_{15} \mathrm{H}_{24} \mathrm{O}_{3}$ by high-resolution ESI-mass measurement. The ${ }^{1} \mathrm{H}$ and ${ }^{13} \mathrm{C}$ NMR spectra (Table 1) in the aid of DEPT and HMQC data revealed the presence of one exocyclic double bond (C-8 and C-12), three methyls (C13, C-14 and C-15), four methylenes (C-1, C-2, C-3 and C6), three methines (C-5, C-7 and C-9) including one oxygen-bearing carbon (C-7), two quaternary carbon (C-4 and $\mathrm{C}-10)$ and one carbonyl carbon (C-11). These data were in good agreement with those of laricinolic acid, a sesquiterpene of the drimane type isolated from the woodrotting fungus Laricifomes officinalis [9]. 2 was confirmed to be identical to laricinolic acid by interpretation of $\mathrm{HMBC}$, which exhibited the long-range correlations from 5-H to C-4, C-9, C-10 and C-13, from 9-H to C-1, C-8, C10, C-11 and C-15, from 12-H to C-7, C-8 and C-9. Other physico-chemical properties were well matched with those of laricinolic acid [9].

Compounds $\mathbf{1}$ and $\mathbf{2}$ were not isolated by following a specific bioassay-guided separation protocol. In a panel for antioxidant effect, however, these compounds exhibited marginal inhibitory activity with an $\mathrm{IC}_{50}$ of $50 \mu \mathrm{g} / \mathrm{ml}$ (vitamin E, $1 \mu \mathrm{g} / \mathrm{ml}$ ) against lipid peroxidation in rat liver microsomes evaluated by the thiobarbituric acid method [10].

Acknowledgement This work was supported by a grant of the Korea Health 21 R\&D Project, Ministry of Health \& Welfare,
Republic of Korea (A-050432).

\section{References}

1. Amousou E, Ayer WA, Browne LM. Antifungal sesquiterpenoids from an arthroconidial fungus. J Nat Prod 52: 1042-1054 (1989)

2. Ayer WA, Saeedi-Ghomi MH. The sterepolides: new isolactaranes from Stereum purpureum. Tetrahedron Lett 22: 2071-2074 (1981)

3. Xie JL, Li LP, Dai ZQ. Isolation and identification of two new metabolites from silver leaf fungus Stereum hirsutum. J Org Chem 57: 2313-2316 (1992)

4. Nair MS, Anchel M. Frustulosinol, an antibiotic metabolite of Stereum frustulosum: Revised structure of frustulosin. Phytochemistry 16: 390-392 (1977)

5. Bu'lock JD, Kaye B, Hudsun AT. New benzofurans from Stereum subpileatum, their biosynthesis, and related processes of aromatic amino acid metabolism in a basidiomycete. Phytochemistry 10: 1037-1046 (1971)

6. Yun BS, Lee IK, Cho YR, Cho SM. New tricyclic sesquiterpenes from the fermentation broth of Stereum hirsutum. J Nat Prod 65: 786-788 (2002)

7. Yun BS, Cho YR, Lee IK, Cho SM, Lee TH, Yoo ID. Sterins $\mathrm{A}$ and B, new antioxidative compounds from Stereum hirsutum. J Antiboit 55: 208-210 (2002)

8. Yoo NH, Yoo ID, Kim JW, Yun BS, Ryoo IJ, Yoon ES, Chinh NT, Kim JP. Sterin C, a new antioxidant from the mycelial culture of the mushroom Stereum hirsutum. Agric Chem Biotech 48: 38-41 (2005)

9. Erb B, Borschberg HJ, Arigoni D. The structure of laricinolic acid and its biomimetic transformation into officinalic acid. J Chem Soc, Perkin Trans 1, 2000: 2307-2309 (2000)

10. Ohkawa H, Ohishi N, Yagi K. Assay for lipid peroxides in animal tissues by thiobarbituric acid reaction. Anal Biochem 95: 351-358 (1979) 